\title{
COMBINED PALAEOFLOOD AND RAINFALL-RUNOFF ASSESSMENT OF MOUNTAIN FLOODS (SPANISH PYRENEES)
}

\author{
M. Rico*, G. Benito*, A. Barnolas** \\ * CSIC-Centro de Ciencias Medioambientales, Serrano 115-bis, 28006 Madrid \\ ** Instituto Tecnológico Geominero de España, Ríos Rosas 23, 28009 Madrid
}

\begin{abstract}
This paper reports a comparative study of the use of palaeohydrological and hydrological techniques to estimate magnitude and frequency of floods applied to two high-gradient, small catchments located in the Spanish Central Pyrenees: the Arás basin, $18.6 \mathrm{~km}^{2}$, and the Montardit basin, $15.2 \mathrm{~km}^{2}$. Palaeohydrological (palaeoflood) techniques, based on palaeostage indicators and the application of both Manning's equation and critical flow equation, were used to estimate discharge values corresponding to seven cross-sections of the Montardit stream. This method yielded discharges ranging from 7 to $112 \mathrm{~m}^{3} \mathrm{sec}^{-1}$. Palaeoflood and historical flood analyses indicated a greater frequency of high magnitude events for both the Arás and Montardit basins than suggested by the application of two different methodologies based on precipitation data (the rational and the unit hydrograph methods). The 1996 Arás basin flood was modelled using the unit hydrograph method, with most reliable results $\left(217 \mathrm{~m}^{3} \mathrm{sec}^{-1}\right)$ obtained using a semidistributed basin model. For small, ungauged mountain basins, palaeoflood reconstruction provides an excellent tool to obtain past flood discharges on which to base the calibration of parameters (e.g. runoff threshold) used in rainfall-runoff methods. It is proposed that the combined results of long-term flood record analysis (based on palaeoflood and historical data) and of standard hydrometeorological methods will aid in the assessment of flood risks for application to the design of emergency measures and floodplain management in ungauged mountain streams.
\end{abstract}

Keywords: Palaeofloods, palaeohydrology, rainfall-runoff methods, mountain stream, Pyrenees, Spain. 


\section{Introduction}

In the Spanish Central Pyrenees, flash floods represent the main natural hazard posing an even greater threat than debris or snow avalanches. Over the last two decades, floods have led to the death of over 100 people. The possibility of an increase in the magnitude and frequency of these extreme floods due to climatic change needs to be considered through the study of long-term flood records in these mountain basins. In addition, many areas of this region that were considered unproductive wastelands during the first half of the $20^{\text {th }}$ Century due to their location on active alluvial fans or close to streams, have since been reclassified by local authorities and used to build housing complexes, recreational areas and campsites. It is foreseen that increased tourist and urban pressures on these mountain areas will lead to the enhanced exposure and vulnerability of material goods or human lives to floods occurring in the small catchments typical of the area.

Flash flood-generating rainfall in the Pyrenees is associated with convectional thunderstorms, which show considerable spatial and temporal variability as shown by the analysis of extraordinary rainfall events recorded in the region during the $20^{\text {th }}$ Century (Albentosa-Sánchez, 1983; Daumas, 1964; Elías and Ruiz, 1979; García-Ruiz et al., 1983; I.N.M., 1998). Research efforts designed to evaluate Pyrenean floods have mainly focused on geomorphological effects (Brú et al., 1984a; Brú et al., 1984b; Corominas and Alonso, 1990; Clotet-Perarnau et al., 1989; Gallart and Clotet-Perarnau, 1988; Gutiérrez et al., 1998; Martí Bono and Puigdefábregas, 1983; Puigdefábregas, 1983) and less frequently describe the hydrological features of these floods (Alcoverro et al., 1999; Batalla et al., 1999; Benito et al., 1998; García-Ruiz et al., 1996).

The evaluation of floods occurring in small mountain drainage basins $\left(<50 \mathrm{~km}^{2}\right)$ requires the precise definition of the spatial and temporal distribution of the rainfall, for which an extensive network of precipitation and streamflow gauging stations is needed. However, since this type of network is rarely available in mountain areas, the consequent lack of data limits the use of rainfall-runoff modelling methods to estimate the magnitude and frequency of floods in this type of basin.

The development of new methods over recent years permits the estimation of peak discharges when the use of conventional rainfall-runoff methods is unreliable. Several authors (Costa, 1987; Jarrett, 1987, 1990a; House, 1991; Martínez-Goytre et al., 1994) report the use of palaeoflood reconstruction methods to estimate the magnitude of 
palaeofloods in small mountain basins. Such methods are based on the field identification of preserved palaeostage indicators and the geometric characteristics of the channel sections that can be used in standard hydraulic procedures for estimating peak discharges. When properly obtained, palaeoflood data may provide long term data applicable to flood frequency analysis, and may represent a more extensive record than the instrumental data sets used in rainfall-runoff methods, thus yielding much more reliable results (Stedinger and Baker, 1987).

The main aim of this study was to apply different flood magnitude and frequency estimation methods (palaeoflood, historical and conventional hydrologic procedures) to two small mountain catchments and thus compare the deficiencies and advantages of each method for application to this type of basin. The study focuses on two high-gradient small, mountain basins in the Spanish Central Pyrenees: the $18.2 \mathrm{~km}^{2}$ Arás basin and the 15.2 $\mathrm{km}^{2}$ Montardit basin. The Arás basin suffered a flash flood in 1996 causing the loss of 87 human lives at a campsite located on the river's alluvial fan. The Montardit basin is an example of a potential high flood risk area having a similar type of human activity such as a campsite and a housing complex in construction on its alluvial fan.

\section{Methods}

Three methodologies were applied to the basins under study: two based on instrumental records, the modified rational and unit hydrograph methods, and a further method based on palaeoflood reconstruction. Data on historical floods of the $20^{\text {th }}$ Century occurring in the two study areas were compiled from documented sources, aerial photographs, historical maps and interviews with the local people.

\subsection{Historical flood data and channel changes}

Data corresponding to the largest historical floods, both regional and local, were compiled in areas for which there was a written record (official and ecclesiastic documents and local chronicles). Interviews with inhabitants were used to provide information on floods occurring at a distance from large communities. These data reflect the direct experience of villagers or events related by the previous generation to their children and provide, especially for the Montardit basin, a detailed record of the largest floods occurring in the $20^{\text {th }}$ Century and of the areas affected by these floods.

Similarly, geomorphological studies may provide information on channel changes through 
time and on the areas affected by flooding. To this end, forms associated with fluvial dynamics and their temporal development were analysed through consecutive aerial photographs and graphical documents (photographs and historical maps), and supported by exhaustive field identification work.

\subsection{Palaeoflood reconstruction. Hydraulic analysis.}

Flood discharges were estimated at different sites along the study streams. The crosssections were surveyed in reaches with evidence of high-water marks (HWM) or palaeostage indicators (PSI) associated with floods. The most common high-water marks found were vegetation debris, which may be close to the water stage during peak discharge. The preservation of such debris may be several decades. The palaeostage indicators used were scars on trees, and gravel bars indicating the minimum level reached by the flood water. These may have a potential preservation of more than 100 years.

Two different methods were used, depending on the hydraulic condition at each site. (1) the critical-depth method in sections where critical flow during floods was assumed and (2) the Manning's equations using the approach suggested by Jarrett $(1984,1985)$ in the estimation of Manning's n roughness coefficient for high-gradient mountain streams. In the present study, these equations were applied in sections with slope ranges from 0.028 to $0.046\left(\mathrm{~m} \mathrm{~m}^{-1}\right)$.

The most accurate peak discharge estimation in high-gradient streams (gradients greater than $0.002 \mathrm{~m} \mathrm{~m}^{-1}$ ) is the critical-depth method (Jarrett, 1987). The critical flow method (Chow, 1959) requires the field selection of sections fulfilling conditions of critical flow, but in contrast, does not depend on the arbitrary estimation of variables such as roughness or slope (O'Connor and Costa, 1993; Benito et al., 1998). For non-rectangular channel sections, critical velocity $\left(V_{c}\right)$ is defined as the square root of the critical depth $\left(y_{c}\right)$ multiplied by the acceleration of gravity $\left(g=9.8 \mathrm{~m} \mathrm{sec}^{-2}\right)$. Stream flow $(Q)$ through the section is calculated using the equation: $Q=A_{c} V_{c}\left(\mathrm{~m}^{3} \mathrm{sec}^{-1}\right)$, where $A_{c}$ is the section area. Using empirical data from numerous channels with slopes greater than $0.002 \mathrm{~mm}^{-1}$, Jarrett $(1984,1985,1987)$ developed an equation that uses energy gradient and hydraulic radius to predict an $n$ value of $n=0.32 R^{0.38} S^{-0.16}$, where $S$ is energy gradient $\left(\mathrm{m} \mathrm{m}^{-1}\right)$ and $R$ is hydraulic radius (m). The Manning's equation may be re-formulated for estimating velocity and discharge in high-gradient natural channels as: 
$V=3.17 R^{0.83} S^{0.12}(1)$

$$
Q=3.17 A R^{0.83} S^{0.12}(2)
$$

where $V$ is the mean flow velocity in $\mathrm{m} \mathrm{sec}^{-1}, Q$ is the discharge in $\mathrm{m}^{3} \sec ^{-1}, A$ is the crosssectional area of flow in $\mathrm{m}^{2}$. The energy gradient $(S)$ is either the energy gradient, or water-surface or bed slope if the channel is relatively uniform (Jarrett, 1990b). In this paper the bed slope has been used.

\subsection{Rainfall-runoff methods: rational and unit hydrograph.}

The rainfall-runoff methods applied were (1) a modified rational method adapted to the specific climatic conditions of Spain, proposed by Témez (1991) and developed by Ferrer (1993), which gives peak discharges for different return periods; and (2) the unit hydrograph method that, in addition, permits the complete reconstruction of the hydrograph. This modified rational method is extensively used in Spain for natural watersheds with surface areas up to $3000 \mathrm{~km}^{2}$ and concentrate time $\left(T_{C}\right)$ ranging from 1 to 24 hours (Témez, 1991; M.O.P.U., 1990). Acording to Témez the following calculation formula can be applied: $Q=(1 / 3.6) C I A K$, where $Q\left(\mathrm{~m}^{3} \mathrm{sec}^{-1}\right)$ is the peak discharge, $I(\mathrm{~mm}$ $\mathrm{h}^{-1}$ ) is the maximum average intensity for the duration interval equal to concentration time, $C$ is the runoff coefficient for the interval in which $I$ is produced, $A\left(\mathrm{~km}^{2}\right)$ is the area of the tributary watershed, and $K$ is the uniformity coefficient.

There are no precipitation gauges located in the studied catchments, therefore rainfall analysis was carried out on the basis of information from the rain-gauge network situated in the surrounding areas. In addition, those rain gauges provide only the total rainfall amount in 24 hours (non-recording type). Statistical analysis of the rainfall data sets involved the application of the two-parameter distribution SQRT-Exponential Type Distribution of Maximum (SQRT-ET $\max$ ), where the parameters are estimated using Maximum Likelihood (ML) estimators. For long return periods, this method gives more realistic and conservative estimates than other two-parameter distributions such as that of Gumbel (Ferrer, 1993).

In the modified rational method for other than daily precipitation data, it is necessary to use intensity-duration-frequency curves. The equation proposed for Spain by Témez (1987) is:

$$
\frac{I_{t}}{I_{d}}=\left(\frac{I_{1}}{I_{d}}\right)^{\frac{28^{0.1}-t^{0.1}}{28^{0.1}-1}}
$$


where $I t\left(\mathrm{~mm} \mathrm{~h}^{-1}\right)$ is the average intensity for the desired duration interval $t$, and $I d\left(\mathrm{~mm} \mathrm{~h}^{-}\right.$ ${ }^{1}$ ) is the average daily rainfall intensity for the return period considered. This relation is a function of one single parameter $I I / I d$, the quotient between the hourly and daily rainfall intensities, which has been regionalised on a national scale and represented in an isohyetal map of II/Id values (Témez, 1991).

To obtain the volume of rainfall leading to surface runoff, the runoff threshold parameter $\left(P_{O}\right)$ was used. This parameter have been related by Ferrer (1993) to the curve number (CN) devised by the S.C.S. (U.S. Soil Conservation Service, S.C.S., 1972), through the equation: $C N=1000 /\left(10+0.2 P_{O}\right)$. The value of the runoff threshold parameter, $P_{O}$, as the curve number, depends on the soil, cover and hydrologic condition of the land surface. Maps were drawn up to define soil types, vegetation and slopes using 1:33000 aerial photographs, 1:25000 orthophotographs and 1:250000 land-use maps. Through fieldwork, the specific maps were completed. The maps were drawn using the different categories of soil, vegetation and land use as defined by the S.C.S. for the calculation of CN. In Spain, this parameter $\left(P_{O}\right)$ needs to be adapted to the rainfall characteristics of the study area using a correction coefficient (Témez, 1991), also regionalised on a national scale. This coefficient reflects the regional variation of background soil moisture conditions before rainfall-produced floods.

Discharge estimates made using the unit hydrograph method involve the use of historical or synthetic storms based on an analysis of long term precipitation data. The lag time $\left(T_{L A G}\right)$ was calculated according to the formula proposed by the S.C.S. for small basins with mainly overland-flow. The HEC-1 programme (U.S. Army Corps of Engineers, 1990) was used to transform the hyetograph into the hydrograph.

\section{Montardit catchment}

The Montardit drainage basin $\left(15.2 \mathrm{~km}^{2}\right)$ is located in the upper basin of the river Noguera Pallaresa, Central Pyrenees (Fig. 1). The basin ranges in altitude from $2364 \mathrm{~m}$ to $660 \mathrm{~m}$ and has a mean slope of $14.9 \%$. At its confluence with the main valley, the stream develops a wide alluvial fan of $1.8 \%$ mean slope.

Figure 2c shows land use and vegetation distribution in the Montardit basin. The natural vegetation of the Central Pyrenees has suffered different levels of alteration in response to human activity. In the Montardit basin, dense woodland has been reduced to a small strip on the northern slope at an altitude of 800 to 1300 metres. Less densely wooded areas 
cover the central zone of the basin and follow the direction of the stream up to an elevation of $1400-1500 \mathrm{~m}$. Above tree line $(1300 \mathrm{~m})$, there is a predominance of high mountain grassland with small amounts of shrub. Most significant cultivated areas are the winter pastures that surround the small basin villages at the final reach of the stream and northern part of the fan.

The middle and upper basins are comprised of slates, shales, limestones, conglomerates and breccias, Palaeozoic in age (Zwart, 1979). The lowermost $2 \mathrm{~km}$ reach of the stream crosses tuffites and andesites, Carboniferous in age, and gypsums, marls and limestones (Keuper facies) of the upper Triassic (Zwart, 1979). These lithologies have favoured lateral erosion of the main channel, and the development of an alluvial bed of $230 \mathrm{~m}$ maximum width, through which the stream flows (Fig. 3). This final reach, with slopes from $3 \%$ to $5 \%$, sedimentologically acts as a transitional environment between the steep mountain stream system and the alluvial fan. The stratigraphy of infill deposits of this reach comprises coarse sediments generated by torrential flow dynamics overlain by fine sediments of homogenous grain size and spatially variable thickness $(0.35-1.45 \mathrm{~m})$. In this reach, upstream from the alluvial fan, aerial photographs from 1957 and historical topographic maps show two abandoned channels (Fig. 3d): one running along the southern edge of the alluvial infill, the main functional channel before artificial channelling; and the other flowing along the northern boundary, which only ever acted as a flood channel during the floods which affected the basin throughout the $20^{\text {th }}$ Century.

The frequent flash floods during the first decades of the $20^{\text {th }}$ Century led to the construction of a canal $900 \mathrm{~m}$ in length along the alluvial fan reach (Fig. 3d and 4). This canal was built between 1925 and 1928 to prevent the continuous overflowing and shifting of the channel during flooding, and to protect the motorway running SW-NE over the fan surface (División Hidrológico-Forestal, 1925). Upstream, the start of the canal is formed by a brick wall that was built at the end of the $19^{\text {th }}$ Century by local inhabitants to protect their crops from repeated flooding (Fig. 3c). During the first decades following its construction, the channelled reach was periodically cleaned, but this practice was subsequently abandoned. Presently, there are large amounts of bed deposits and in many places, the vegetation has colonised these deposits, markedly reducing the channel section and therefore the stream's conveyance capacity. The channelisation project was based on the two largest floods of the previous 20 years before its construction in 1925. This lack of data and maintenance resulted in the incorrect dimensions of the structure, which became 
obvious in the flood of 1944.

In the 1957 aerial photograph, the system of flood protection walls and a depositional lobe may be seen to occupy the middle and central distal area of the fan (Fig. 3c and d). To the north and south of this lobe there are no signs of recent (post-1957) fan activity in any of the graphical documents consulted. At the beginning of the 1990's, housing construction started on the most recently active sector of the fan and affected a large part of the depositional lobe (Fig. 3d). A campsite is presently located on the southernmost area of the fan, bounded to the north by the Montardit stream and to the south by the Noguera Pallaresa River and another small tributary stream.

The following historical floods have been recorded in the Montardit region of the Noguera Pallaresa River: 1348, January 1433, autumn 1436, 1617, 1637, 1753, 1853, 1894, October 1907, October 1937, August 1963, November 1963, November 1967, April 1971, November 1982, September 1983 and November 1984 (Coy y Cotonat, 1906; Comisión Técnica de Inundaciones, 1985). However, no significant damage was registered on any of these dates in the Montardit basin.

The first reference of major flooding of the Montardit stream is that of November 1907 (Fig. 3a), although no major damage was reported. In August 1924 (Fig. 3b), a flood provoked the shifting of the channel and its waters invaded the northern side of the final reach and flooded the village, with reports of two metres of water in some houses. In 1929, the channelisation works were completed. In 1944 (Fig. 3c), a local storm caused great damage to the area as the strength of the water and transported materials broke the lateral containment wall of the canal. The stream flowed in its original natural course flooding the crops along its way. Transported materials were deposited in the middle and distal areas of the fan forming the lobe of boulders and gravel shown in the aerial photograph taken in 1957 (Fig. 3c). It is of note that the rainfall, during the 1944 event, was localised to such an extent that no substantial rainfall was recorded by any of the precipitation gauges close to the basin.

\subsection{Palaeoflood reconstruction. Hydraulic analysis.}

Seven cross-sections of the stream channel were selected (Fig. 2a). The first four crosssections (1, 2, 3 and 4) were chosen for their relatively stable geometry and due to their location a few metres upstream of a waterfall where critical flow during flooding was assumed. Flow stage indicators were obtained on-site, the most frequent being drift wood 
and gravel bar surfaces.

The remaining cross-sections (5, 6 and 7) are located in the lowest part of the basin. All three sections were selected for their high risk of overflowing during floods. Discharge values and bankfull peak discharges for these reaches were estimated using the Manning equation as modified by Jarrett $(1984,1985)$ for high-gradient streams (Eq. (1) and (2)). In these cross-sections (5, 6 and 7), full filling conditions of critical flow are not attained, however the high gradient and frequent changes in channel slope point to Froude number values varying around 1. A second discharge estimation for these cross-sections $(5,6$ and 7) using the critical flow equation was obtained.

Sections 5 to 7 were taken along a partially filled canal (Fig. 4), in stretches that are currently of smallest capacity and therefore present the greatest risk of overflowing during a flood. For each section, two possible situations were considered: (1) peak discharge flowing through the clean, deposit-free canal; and (2) peak discharge, taking into account current vegetation and canal infill. The results shown in Table 1 indicate there is up to a $25 \%$ reduction in peak discharge when vegetation and canal infill are considered. At section 7, a water stage indicator of a recent (last 5 years) flood suggested discharges about $11 \mathrm{~m}^{3} \mathrm{sec}^{-1}$, representing low-magnitude floods. Estimated discharges were comparable to those obtained for cross-sections 1 to 4 (Table 1).

\subsubsection{Results}

Table 1 shows the results of the palaeoflood reconstruction. The highest peak discharge, based on a palaeostage indicator (scar on tree), was $112 \mathrm{~m}^{3} \mathrm{sec}^{-1}$ for cross-section 3 . This value would correspond to a low-frequency flood occurring in the basin. Remaining discharges, based on high-water marks and palaeostage indicators, generally ranged from 7 to $46 \mathrm{~m}^{3} \mathrm{sec}^{-1}$ and correspond to recent low-magnitude, high-frequency floods. Comparing the estimated discharges at the lowest cross-sections (5-7) with the ones obtained in the uppermost cross-sections (1-4) we may consider the estimation from Manning's equation provide conservative discharge values whereas the ones resulting from the critical flow equation seems to represent a closer estimation.

Considering present-day channel geometry, bank overflow (bankfull) discharge in the stream's final channelled reach on the alluvial fan (cross-sections $6 \& 7$ ) will be attained at a discharge of $59 \mathrm{~m}^{3} \mathrm{sec}^{-1}$. In cross-section 6, surveyed in the reach that overflowed during the 1944 flood, the bankfull peak discharge calculated for the deposit-free channel 
was $79 \mathrm{~m}^{3} \mathrm{sec}^{-1}$.

Future floods surpassing $59 \mathrm{~m}^{3} \mathrm{sec}^{-1}$ would provoke an abrupt change in spatial flow patterns and flood waters would inundate the topographically lower areas, which are presently occupied by cultivated land, a housing complex and the village of Ribera de Montardit. A more accurate assessment of the potential flood risk associated with these constructions would require a detailed topographic survey and hydrologic calculations of the alluvial fan.

\subsection{Rainfall-runoff methods}

An aggregate basin model was considered for both the rational and unit hydrograph methods, due to the lack of major subcatchments. For the pluviometric analysis, a data set was compiled using the highest rainfall value recorded within a 24 hour period for each year from each of 11 rain gauges (non-recording type) close to the basin. The reduction factor per area $\left(K_{A}\right)$ was estimated through the following equation, $K_{A}=1-\left(\log _{10} A / 15\right)$, where $A$ is the surface area of basin, in $\mathrm{km}^{2}$, yielding a value of 0.92 . Areal precipitation $\left(P_{A}\right)$ was calculated using the modified Thiessen method and the results are shown in Table 2. The I1/Id ratio for this area has an assigned value of 11 (Témez, 1991).

The thematic maps required for the calculation of the runoff threshold, $P_{O}$, using the S.C.S. method are shown in Figure 2. Once the runoff threshold correction factor, which takes on a value of 1.8 in this area (Témez, 1991), was applied, resultant runoff thresholds were $26.2 \mathrm{~mm}$. As the available precipitation gauges only record one measurement every 24 hours there are no available data for defining a historic storm, thus synthetic hyetographs was obtained using an intensity-duration curve. The following equation is proposed by Témez (1991) for the modified rational method:

$I(d)=\left(\frac{P d}{24}\right)\left(\frac{I 1}{I d}\right)^{\frac{28^{0.1}-d^{0.1}}{28^{0.1}-1}}$

where $I(\mathrm{~d})\left(\mathrm{mm} \mathrm{h}^{-1}\right)$ is the average intensity for the desired duration interval, $d, P d(\mathrm{~mm})$ is the daily rainfall depth, $(I I / I d)$ is the quotient between the hourly and daily rainfall intensities, and $d(\mathrm{~h})$ is the time increments. Model applied herein is a $28 \mathrm{~h}$ centred synthetic hyetograph with symmetrical distribution of rainfall. The equations recommended for each method were used to calculate the time parameters: concentration time $\left(T_{C}\right)$ in the rational method and lag time $\left(T_{L A G}\right)$ in the unit hydrograph method. These 
results are shown in Table 3.

\subsubsection{Results}

If these results are compared to discharges estimated through palaeoflood reconstruction, it may be observed that the most frequent flood episodes of 7 to $46 \mathrm{~m}^{3} \mathrm{sec}^{-1}$ derived from palaeostage indicators are similar to those obtained for rainfall events with return periods of 2 to 25 years. The cross-section 6 coincides with the reach that overflowed during the 1944 flood. The maximum peak discharge estimated to flow through this section was 79 $\mathrm{m}^{3} \mathrm{sec}^{-1}$, indicating that over the last 70 years, a flood of similar discharge was produced at least once. These values area also attained by floods with return periods of over 100 years.

High-water marks in cross-section 1 (upstream of the channelled reach) provided discharge estimates of up to $108 \mathrm{~m}^{3} \mathrm{sec}^{-1}$. This discharge may correspond to the 1944 flood which did not overflow banks in cross-section 5 (bankfull discharge of $123 \mathrm{~m}^{3} \mathrm{sec}^{-1}$ ) but it did at cross-section 6 (bankfull discharge of $79 \mathrm{~m}^{3} \mathrm{sec}^{-1}$ ). In cross-section 3, high water marks associated with discharge estimates of $112 \mathrm{~m}^{3} \mathrm{sec}^{-1}$ may correspond to a previous flood (1907 or 1924). Magnitude ranking for the $20^{\text {th }}$ Century floods $(1907,1924$ and 1944) is difficult to establish because the flood potential effects (level of perception by inhabitants) were modified by the canal construction in 1929. Nevertheless, according to interviews, the 1924 flood was bigger than the 1944 one. Another fact is that two flood of a similar magnitude $\left(\mathrm{Q}>79 \mathrm{~m}^{3} \mathrm{sec}^{-1}\right)$ occurred in a 21-year interval, which according to hydrometeorological methods would correspond to return periods over a 100-years.

\section{Arás catchment}

The Arás stream flows through the upper basin of the Gállego River in the Spanish Central Pyrenees (Fig. 1). Its drainage basin covers an area of $18.6 \mathrm{~km}^{2}$ with an elevation range of $2189 \mathrm{~m}$ to $838 \mathrm{~m}$ (Fig. 5a). At its confluence with the Gállego valley, it develops an alluvial fan of $0.73 \mathrm{~km}^{2}$ and $6.5 \%$ slope. At the start of the $20^{\text {th }}$ Century, a canal was constructed, crossing the Arás fan from its apex to the Gállego River (Fig. 5a).

On August $7^{\text {th }} 1996$, a catastrophic flood caused the death of 87 people at a campsite located on the alluvial fan of the Arás basin (Fig. 5a). During that day, heavy rainfall had been recorded in the area, with a maximum of $153 \mathrm{~mm}$ in one hour and $252.5 \mathrm{~mm}$ during the 6 hours of the storm (I.N.M., 1998). Total daily rainfall recorded at the closest 
precipitation gauge in Biescas was $160.0 \mathrm{~mm}$.

In agreement with studies performed by Batalla et al. (1999), the flood power range was 20000 to $40000 \mathrm{Wm}^{-2}$ on average, capable of entraining boulders of up to $10 \mathrm{~m}$ in diameter. According to estimations made by García-Ruiz et al. (1996), around $68000 \mathrm{~m}^{3}$ of sediments were transported during the flood. Benito et al. (1998) evaluated discharges generated by the flood of August 1996 at 9 sections of the entire stream system formed by the Arás watershed through the application of two methods: the use of Manning's equation and the critical flow method. The peak discharge, of approximately $430 \mathrm{~m}^{3} \mathrm{sec}^{-1}$, was determined upstream from the alluvial fan apex using the critical flow equation. Alcoverro et al. (1999) similarly obtained peak discharge values of 400 to $600 \mathrm{~m}^{3} \mathrm{sec}^{-1}$ using the critical flow method.

\subsection{Modelling the August $7^{\text {th }}$ storm.}

The HEC-1 programme was used to model the rainfall-runoff process in the Arás basin applying both an aggregate model and a semidistributed model in which three subbasins and an independent final reach were identified. The rational method, based on available precipitation data for this day, was also applied. Areal precipitation $\left(P_{A}\right)$ was calculated for each subbasin using the isohyetal map drawn up by the National Weather Institute (I.N.M.) from corrected radar data corresponding to August $7^{\text {th }}$ 1996. Temporal distribution was obtained from hourly accumulated rainfall data, estimated by radar and corrected using pluviometric data. A runoff threshold of $19 \mathrm{~mm}$ was estimated for high pre-storm soil moisture conditions. The thematic maps required for the calculation of the runoff threshold, $P_{O}$, using the S.C.S. method are shown in Figure $5 \mathrm{~b}$ and $5 \mathrm{c}$. Hydrographs corresponding to each sub-basin were combined and propagated according to Muskingham's method, using a value of 0.4 for the $X$ parameter and a wave celerity $(C)$ of $2 \mathrm{~m} \mathrm{~s}^{-1}$ along the $1200 \mathrm{~m}$ reach downstream from the junction of the three subcatchments. The results (Table 4) reflect the similarity between discharges estimated by the rational method $\left(182 \mathrm{~m}^{3} \mathrm{sec}^{-1}\right)$ and the unit hydrograph method $\left(185 \mathrm{~m}^{3} \mathrm{sec}^{-1}\right)$ using an aggregate basin model and runoff threshold calculated according to the S.C.S. method. In contrast, higher values $\left(217 \mathrm{~m}^{3} \mathrm{sec}^{-1}\right)$ were obtained using a semidistributed basin model.

A large difference is observed between peak discharge values estimated using rainfallrunoff methods (up to $217 \mathrm{~m}^{3} \mathrm{sec}^{-1}$ ) and those obtained through hydraulic estimations $\left(>430 \mathrm{~m}^{3} \mathrm{sec}^{-1}\right)$ using high water marks at critical flow sections according to Benito et al. 
(1998). The rainfall-runoff models used here are only able to estimate runoff generated by a particular precipitation value, i.e. they do not take into account the solid transportable volume available in the basin. According to estimates made by García-Ruiz (1996), some $68000 \mathrm{~m}^{3}$ of sediments were transported during the flood. Most of these sediments were provided by the collapse of 31 sediment retention dams located along the lowest $1 \mathrm{~km}$ reach of the Arás stream.

On one hand, we can speculate that the difference in peak discharge estimation can be due to problems associated with the flow having a debris flow component (multiphase flow) associated with each dam collapse, which could generate an unsteady wave or pulse. On the other hand, discharges provided by rainfall-runoff methods are highly sensitive to the runoff threshold parameter $\left(P_{O}\right)$. This parameter is estimated according to the physical characteristics of the basin which vary according to the season or year, such as the type of vegetation, land use and soil moisture prior to the flood-causing event. It is thus advisable to estimate $P_{O}$ by calibration through the comparison of discharges given by rainfallrunoff methods and the statistical analysis of historical extreme discharges. In small basins, for which sets of extreme discharge data are rarely available, palaeoflood reconstruction methods applied to historical storms are a useful tool. Peak discharges similar to those estimated by Benito et al. (1998) for the final part of the stream, may be obtained by incorporating runoff threshold values of the order of 4-5 $\mathrm{mm}$ (Table 4) into the model, and considering the total discharge as the sum of the runoff (up to $362 \mathrm{~m}^{3} \mathrm{sec}^{-1}$ ) and sediment volume carried by the flow (up to a mean of $75 \mathrm{~m}^{3} \mathrm{sec}^{-1}$ ), assuming that most of this transport occurred over the 10-15 minute duration of the peak flood as related by eye-witness accounts of this catastrophic flood.

\section{Conclusions}

The present paper shows how palaeoflood studies may provide valuable information on the magnitude of 'real' floods occurring in small ungauged mountain basins or when available data sets are not too reliable. Three high magnitude floods of the $20^{\text {th }}$ Century in the Montardit catchment area were documented through interviews with the locals and their effects analysed using sequential aerial photographs. There is no record of these events at gauging stations or in regional historical flood registers. The floods of the Montardit and Arás streams of the last decades clearly indicate that flash flood generating storms in small Pyrenean catchments are much more common than those predicted by 
precipitation series frequency analysis using data from nearby precipitation gauges.

The results of the different models applied to the Montardit drainage basin suggest that for high-frequency, low-magnitude rainstorms there is a good correlation between peak discharge values estimated through palaeoflood reconstruction and those provided by rainfall-runoff methods. In contrast, evaluation of high magnitude rainstorms indicates a higher historical frequency than that predicted by rainfall-runoff modelling. The main reason for this discrepancy is that the extreme rainfall generating such floods in small basins is rarely monitored. The lack of historical extreme episodes in precipitation data series limits the use of rainfall-runoff methods for the analysis of extraordinary floods. This drawback has been partly resolved by the development and application of palaeohydrological techniques that provide information on the magnitude of extraordinary past floods over long-time intervals (100 to 1000 years) far beyond the corresponding instrumental record (if available). Thus, only the combined use of both methods yields the necessary information to define the temporal and spatial occurrence of floods in small mountain watersheds.

Further, results obtained using rainfall-runoff methods are highly sensitive to the runoff threshold value employed and it is advisable to estimate this parameter by empirical comparison with real flood discharge values for each basin or similar basins in the region. Thus, for small ungauged mountain basins, palaeoflood reconstruction is an indispensable tool to estimate past flood discharges on which to base the calibration of parameters (e.g. runoff threshold) by comparison with the results yielded by rainfall-runoff methods.

\section{ACKNOWLEDGEMENTS}

The authors are grateful to the Consell Comarcal del Pallars Sobirà (Lleida, Spain) for assistance in the field survey and to Varyl R. Thorndycraft for his help with the English. This research was funded by the Instituto Geominero de España (ITGE), and by the European Commission (DGXII), through research contract number EVG1-CT-199900010 (Systematic, Palaeoflood and Historical data for the improvEment of flood Risk Estimation "SPHERE” Project). Reviews by V.R. Baker and R.D. Jarrett significantly improved the manuscript. 


\section{REFERENCES}

Albentosa-Sánchez, L., 1983. Precipitaciones excepcionales e inundaciones durante los días 6 al 8 de Noviembre de 1982 en Cataluña. Estud. Geogr., 170-171: 229-273

Alcoverro, J., Corominas, J. and Gómez, M., 1999. The Barranco de Arás flood of 7 August 1996, Biescas, Central Pyrenees, Spain). Eng. Geol., 51: 237-255.

Batalla, R.J., Jong, C., Ergenzinger, P. and Sala, M., 1999. Field observations on hyperconcentrated flows in mountain torrents. Earth Surf. Process. Landforms 24: 247253.

Benito, G., Grodek, T. and Enzel, Y., 1998. The geomorphic and hydrologic impacts of the catastrophic failure of flood-control-dams during the 1996-Biescas flood (Central Pyrenees, Spain). - Z. Geomorph. N. F.,42 (4): 417-437.

Brú, J., Julià, R. and Marqués, M.A., 1984a. El movimiento de masa de Pont de Bar. Inestabilidad de laderas en el Pirineo. Escuela Técnica Superior de Ingenieros de Caminos, Canales y Puertos, Barcelona, pp. I.2.1-I.2.10.

Brú, J., Serrat, D. and Vilaplana, J.M., 1984b. La dinámica geomorfológica de la cuenca del torrente de Jou-La Guingueta (Noguera Pallaresa). Inestabilidad de laderas en el Pirineo. Escuela Técnica Superior de Ingenieros de Caminos, Canales y Puertos, Barcelona, pp. I.2.1-I.2.10.

Chow, V.T., 1959. Open-channel hydraulics. McGraw Hill, New York.

Clotet-Perarnau, N., García-Ruiz, J.M. and Gallart, F., 1989. High magnitude geomorphic work in Pyrenees range: unusual rainfall event, November 1982. Stud. Geomorph. Carpatho-Balcanica, 23: 69-90.

Comisión Técnica de Inundaciones, 1985. Estudio de inundaciones históricas: mapa de riesgos potenciales, Comisión Nacional de Protección Civil, IV-VIII.

Corominas, J. and Alonso, E., 1990. Geomorphological effects of extreme floods (November 1982) in the Southern Pyrenees. Proceedings of two Lausanne Symposia, August, 1990. Hydrology in Mountains Regions: II. Artificial Reservoirs; Water and Slopes 194 I.A.H.S. Publication, pp. 295-302.

Costa, J.E., 1987. Hydraulics and basin morphometry of the largest flash flood in the conterminous United States. J. Hydrol. Amsterdam, 93: 313-338.

Coy y Cotonat, A., 1906. Sort y comarca Noguera-Pallaresa. Imprenta y Litografía de la Viuda de José Cunill, Barcelona. (Reprinted 1974, Romargraf, S.A. Barcelona).

Daumas, M., 1964. Les crues du 3 Août 1963 dans les hautes vallées aragónaises et 
catalanes. Rev. Geogr. et S.O., 35: 305-310.

División Hidrológico-Forestal, $1^{\mathrm{a}}$, 1925. Proyecto de corrección del Torrente de Montardit. Encauzamiento. Memoria. Technical report, División Hidrológico-Forestal, ICONA, Madrid.

Elías, F. and Ruiz, L., 1979. Precipitaciones máximas en España. ICONA Monografías no 21, Madrid.

Ferrer, J. 1993. Recomendaciones para el cálculo hidrometeorológico de avenidas. CEDEX M-37, Madrid.

Gallart, F. and Clotet-Perarnau, N., 1988. Some aspects of the geomorphic processes triggered by an extreme rainfall event: the November 1982 flood in the Eastern Pyrenees. Catena Suppl. 13: 79-95.

García-Ruiz, J.M. and Puigdefábregas, J. and Martín, M.C., 1983. Diferencias espaciales en la respuesta hidrológica a las precipitaciones torrenciales de Noviembre de 1982 en el Pirineo Central. Estud. Geogr., 170-171: 291-310.

García-Ruiz, J.M., White, S.M., Martí, C., Valero, B., Errea, M.P. and Gómez Villar, A., 1996. La catástrofe del barranco de Arás (Biescas, Pirineo Aragonés) y su contexto espacio-temporal. CSIC-IPE, Zaragoza.

Gutiérrez, F., Gutiérrez, M. and Sancho, C., 1998. Geomorphological and sedimentological analysis of a catastrophic flash flood in the Arás drainage basin (Central Pyrenees, Spain). Geomorphology, 22: 265-283.

House, P.K., 1991. Paleoflood hydrology of the principal canyons of the southern Tortolita Mountains, southeastern Arizona. Arizona Geological Survey Open File Report, 91-6: 22 pp.

I.N.M.(Instituto Nacional de Meteorología), 1998. Estudio meteorológico de la situación del 7 de Agosto de 1997 (Biescas). Nota Técnica STAP no 26. Nota Técnica CMT de Aragón, La Rioja y Navarra $n^{\circ} 1$., Madrid.

Jarrett, R.D., 1984. Hydraulics of high-gradient streams. J. Hydraul. Div. Am. Soc. Civ. Eng., 110: 1519-1539.

Jarrett, R.D., 1985. Determination of roughness coefficient for streams in Colorado. U.S. Geol. Surv. Water Resour. Invest., Report 85-4004.

Jarrett, R.D., 1987. Errors in slope-area computations of peak discharges in mountain streams. J. Hydrol. Amsterdam, 96:53-67.

Jarrett, R.D., 1990a. Paleohydrologic techniques used to define the spatial occurrence of 
floods. Geomorphology, 3: 181-195.

Jarrett, R.D., 1990b. Hydrologic and hydraulic research in mountain rivers. Water Resources Bulletin, 26 (3): 419-429.

Martí Bono, C. and Puigdefábregas, J., 1983. Consecuencias geomorfológicas de las lluvias de Noviembre de 1982 en las cabeceras de algunos valles pirenaicos. Estud. Geogr., 170-171: 275-290.

Martínez-Goytre, J., House, P.K. and Baker, V.R., 1994. Spatial variability of small-basin paleoflood magnitudes for a southeastern Arizona mountain range. Water Resour. Res., 30 (5): 1491-1501.

M.O.P.U. (Ministerio de Obras Públicas y Urbanismo), 1990. Instrucción 5.2-IC. Drenaje superficial. Dirección General de Carreteras. M.O.P.U., Madrid.

O'Connor, J.E. and Costa, J.E., 1993. Geologic and hydrologic hazards in glacierized in North America resulting from $19^{\text {th }}$ and $20^{\text {th }}$ Century global warming. Natural Hazards, 8: 121-140.

Puigdefábregas, C., 1983. Efectes geomorfològics dels aiguats del Novembre de 1982. Informes 1. Servei Geològic de Catalunya, Barcelona.

Stedinger, J.R. and Baker, V.R., 1987. Surface water hydrology: historical and paleoflood information. Reviews of Geophysics, 25: 119-124.

Témez, J.R., 1987. Cálculo hidrometeorológico de caudales máximos en pequeñas cuencas naturales. Dirección General de Carreteras, M.O.P.U., Madrid.

Témez, J.R., 1991. Extended and Improved Rational Method. Version of the Highways Administration of Spain. Proc. XXIV Congress. Madrid, Spain,. Vol A., pp. 33-40.

U.S. Army Corps of Engineers, 1990. HEC-1: Flood Hydrograph Package, User's manual.

U.S. Hydrologic Engineering Center, Davis, California

U.S. Soil Conservation Service, 1972. National Engineering Handbook, Sec. 4, Hydrology, U.S. Department of Agriculture, Washington D.C.

Zwart, H.J., 1979. The Geology of the Central Pyrenees. Leidse Geologische Mededelingen, Leiden. 


\section{TABLES}

Table 1. Measured and estimated hydraulic parameters for several high-water marks and palaeostage indicators obtained at the different cross-sections of the Montardit stream (Fig. 2a).

Table 2. Areal precipitation $\left(P_{A}\right)$ for different recurrence periods $(T)$ estimated for the Montardit basin.

Table 3. Discharges estimated for the Montardit basin according to the rational (modified by Témez, 1991) and unit hydrograph methods for different recurrence periods.

Table 4. Peak discharges estimated for the August $7^{\text {th }} 1996$ flood by the rational and unit hydrograph methods, for runoff threshold values derived from the curve number $(C N)$ after the U.S. Soil Conservation Service (1972) (a). In (b) runoff threshold values were calibrated to obtain the peak discharges close to the ones estimated by Benito et al. (1998) for this flood.

\section{FIGURES}

Fig. 1. Location map of the study areas.

Fig. 2. Location of the Montardit catchment and detail maps showing (a) topography (contour interval is $100 \mathrm{~m}$ ), (b) hydrologic soil classes and (c) vegetation and land uses.

Fig. 3. Diagram of the alluvial fan and final reach of the Montardit stream showing the most significant historical floods of the $20^{\text {th }}$ Century ( $a, b$ and $c$ ) and current topography (d).

Fig. 4. View of the channelled reach, upstream of cross-section 7 (canal's wide: $9.2 \mathrm{~m}$ ).

Fig. 5. Mapping of the Arás basin: topography and diagram of the alluvial fan (a), hydrological soil classes (b), and vegetation and land use (c) characteristics. 


\begin{tabular}{|c|c|c|c|c|c|c|c|c|c|c|c|}
\hline Site & $\begin{array}{c}\text { Stage* } \\
\text { indicators }\end{array}$ & Method $^{* *}$ & $\begin{array}{c}\text { A } \\
\left(m^{2}\right) \\
\end{array}$ & $\begin{array}{c}\mathrm{R} \\
(\mathrm{m}) \\
\end{array}$ & $\begin{array}{c}\mathrm{S} \\
\left(\mathrm{m} \mathrm{m}^{-1}\right) \\
\end{array}$ & $\begin{array}{c}V c^{\star \star \star} \\
\left(m \sec ^{-1}\right)\end{array}$ & $\begin{array}{c}\text { Qc } \\
\left(\mathrm{m}^{3} \sec ^{-1}\right)\end{array}$ & $n$ & $\begin{array}{c}\mathrm{V}^{* \star \star *} \\
\left.(\mathrm{~m} \mathrm{sec})^{-1}\right)\end{array}$ & $\begin{array}{c}Q \\
\left(\mathrm{~m}^{3} \sec ^{-1}\right)\end{array}$ & $\begin{array}{l}\text { Froude } \\
\text { number }\end{array}$ \\
\hline \multirow[t]{2}{*}{1} & HWM & $\mathrm{CF}$ & 14.4 & 0.58 & 0.075 & 4.2 & 60 & --- & --- & --- & --- \\
\hline & HWM & $\mathrm{CF}$ & 23.6 & 0.87 & 0.075 & 4.6 & 108 & --- & ---- & --- & ---- \\
\hline \multirow[t]{2}{*}{2} & HWM & CF & 7.6 & 0.84 & 0.152 & 4.1 & 31 & ---- & ---- & ---- & ---- \\
\hline & HWM & $\mathrm{CF}$ & 5.7 & 0.72 & 0.152 & 3.8 & 21 & --- & --- & --- & ---- \\
\hline \multirow[t]{6}{*}{3} & HWM & $\mathrm{CF}$ & 9.5 & 0.45 & 0.123 & 3.3 & 31 & ---- & --- & --- & --- \\
\hline & HWM & $\mathrm{CF}$ & 5.4 & 0.28 & 0.123 & 2.9 & 16 & --- & --- & --- & ---- \\
\hline & HWM & CF & 2.6 & 0.37 & 0.123 & 2.5 & 7 & --- & --- & --- & ---- \\
\hline & PSI & $\mathrm{CF}$ & 9.5 & 0.45 & 0.123 & 3.3 & 31 & --- & --- & ---- & --- \\
\hline & HWM & $\mathrm{CF}$ & 13.1 & 0.60 & 0.123 & 3.5 & 46 & --- & --- & --- & ---- \\
\hline & PSI & $\mathrm{CF}$ & 26.0 & 1.12 & 0.123 & 4.3 & 112 & --- & ---- & ---- & ---- \\
\hline \multirow[t]{2}{*}{4} & HWM & $\mathrm{CF}$ & 2.6 & 0.33 & 0.144 & 2.5 & 7 & --- & ---- & ---- & --- \\
\hline & HWM & $\mathrm{CF}$ & 6.6 & 0.72 & 0.144 & 3.4 & 22 & ---- & --- & ---- & --- \\
\hline \multirow[t]{2}{*}{5} & $B(1)$ & $\mathrm{CF} / \mathrm{M}$ & 19.1 & 1.36 & 0.046 & 5.2 & 99 & 0.095 & 2.8 & 54 & 0.54 \\
\hline & $B(2)$ & $\mathrm{CF} / \mathrm{M}$ & 24.4 & 1.70 & 0.046 & 5.2 & 127 & 0.091 & 3.4 & 83 & 0.65 \\
\hline \multirow[t]{2}{*}{6} & $\mathrm{~B}(1)$ & $\mathrm{CF} / \mathrm{M}$ & 12.7 & 1.14 & 0.046 & 4.6 & 59 & 0.097 & 2.4 & 31 & 0.53 \\
\hline & B (2) & $\mathrm{CF} / \mathrm{M}$ & 17.0 & 1.32 & 0.046 & 4.6 & 79 & 0.095 & 2.8 & 47 & 0.59 \\
\hline \multirow[t]{3}{*}{7} & PSI & $\mathrm{CF} / \mathrm{M}$ & 4.6 & 0.46 & 0.028 & 2.4 & 11 & 0.093 & 1.1 & 5 & 0.46 \\
\hline & $B(1)$ & $\mathrm{CF} / \mathrm{M}$ & 14.7 & 1.20 & 0.028 & 4.0 & 59 & 0.080 & 2.4 & 35 & 0.60 \\
\hline & B (2) & CF/M & 15.1 & 1.21 & 0.028 & 4.0 & 61 & 0.080 & 2.4 & 37 & 0.60 \\
\hline
\end{tabular}

A: Cross-sectional flow area; R: Hydraulic radius; S: Channel slope; $n$ : Manning coefficient according to Jarrett's equation for high-gradient streams $\left(n=0.32 S^{0.38} R^{-0.16}\right)$

* HWM: High Water Marks; PSI: Palaeostage Indicators; B: Bankfull stage (1: current conditions; 2: clean conditions)

** Calculation method: M: Manning's equation; CF: Critical flow equation

*** Vc and Qc: Flow velocity and discharge assuming critical flow

**** $V$ and $Q$ : Mean flow velocity and discharge using Manning's equation 
$\begin{array}{lllllll}\text { T (years): } & 2 & 5 & 10 & 25 & 50 & 100\end{array}$

$\begin{array}{lllllll}\mathbf{P}_{\mathrm{A}}(\mathbf{m m}): & 55 & 71 & 81 & 96 & 108 & 120\end{array}$ 


\begin{tabular}{lcccccccc} 
Method $^{*}$ & $\mathrm{P}_{\mathrm{O}}$ & $\mathrm{T}^{* *}$ & $\mathrm{Q}^{* * *}$ & $\mathrm{Q} 5$ & $\mathrm{Q} 10$ & $\mathrm{Q} 25$ & $\mathrm{Q} 50$ & Q100 \\
\hline U.H.M. & 26 & $\mathrm{~T}_{\text {LAG }}$ & 8 & 19 & 29 & 44 & 58 & 72 \\
M.R.M. & 26 & $\mathrm{~T}_{\mathrm{C}}$ & 13 & 24 & 32 & 46 & 58 & 70 \\
\hline
\end{tabular}

$\mathrm{P}_{\mathrm{O}}$ : Runoff threshold (mm)

* Calculation methods: U.H.M.: Unit Hydrograph Method; M.R.M.: Modified Rational Method

** $\mathrm{T}$ : Time parameters (in hours): $\mathrm{T}_{\mathrm{LAG}}$ : Lag time; $\mathrm{T}_{\mathrm{C}}$ : Concentration time

${ }^{* \star *} \mathrm{Q} 2, \mathrm{Q} 5, \ldots$. Peak discharges $\left(\mathrm{m}^{3} \mathrm{sec}^{-1}\right)$ for each recurrence period: $2,5, \ldots$ years 
(a) $\mathrm{P}_{\mathrm{O}}=19$

Method $^{*} \quad P_{A} \quad Q_{a}^{* *} \quad Q_{b}^{* *}$

$(\mathrm{mm})$

(mm) $\quad\left(\mathrm{m}^{3} \sec ^{-1}\right)\left(\mathrm{m}^{3} \sec ^{-1}\right)$

\begin{tabular}{lllc}
\hline M.R.M. & 180 & 182 & --- \\
U.H.M. & 180 & 185 & 217
\end{tabular}

(b) $P_{O}=4$

$(\mathrm{mm})$

$\begin{array}{lll}\text { M.R.M. } & 180 \quad 264\end{array}$

U.H.M. $\quad 180 \quad 362$

$\mathrm{P}_{\mathrm{O}}$ : Runoff threshold $(\mathrm{mm}) ; \mathrm{P}_{\mathrm{A}}$ : areal precipitation for the August $7^{\text {th }} 1996$ storm

* Calculation methods: M.R.M.: Modified Rational Method; U.H.M., Unit Hydrograph Method

** $Q$ : Peak discharge estimated using an aggregate $\left(Q_{a}\right)$ or semidistributed $\left(Q_{b}\right)$ basin model 


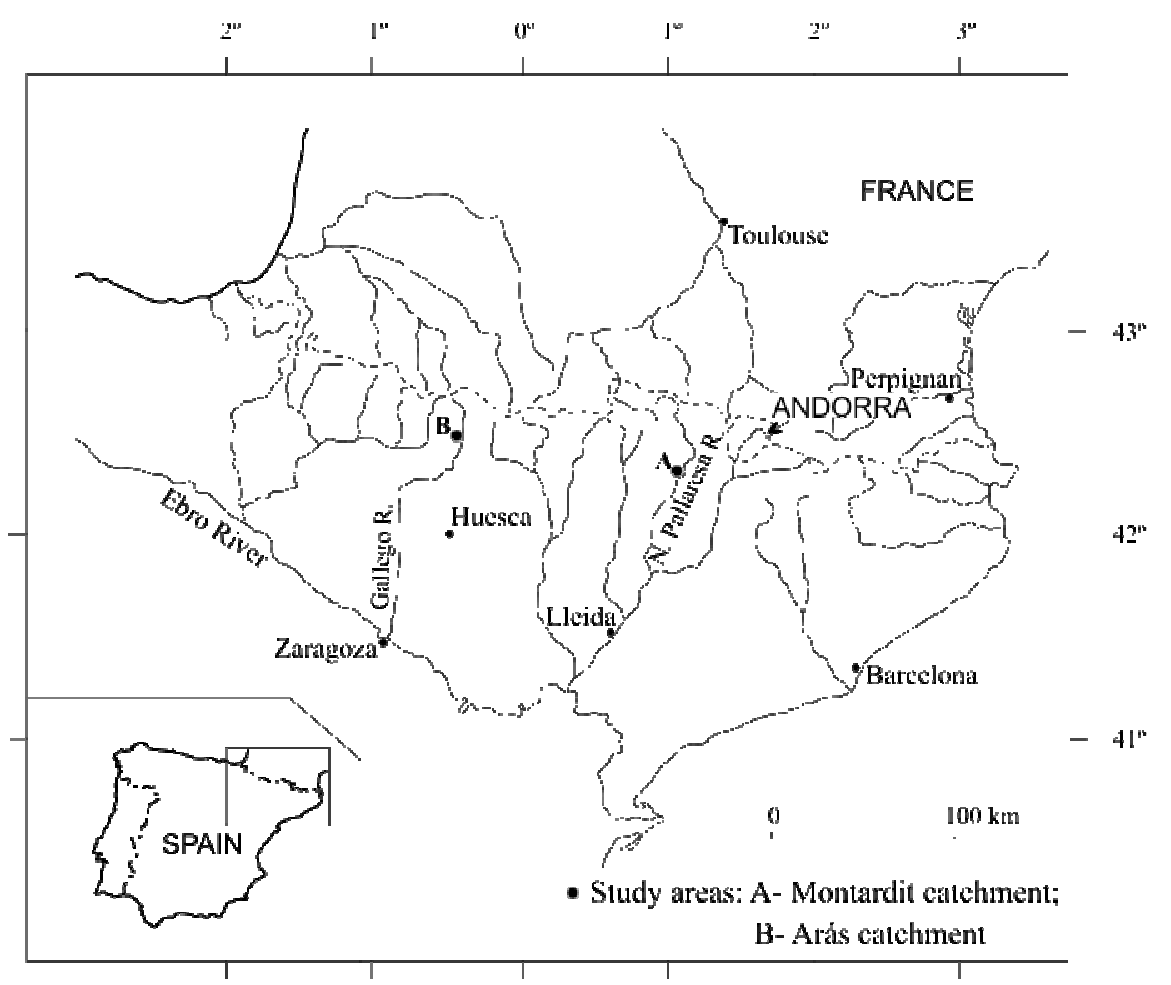



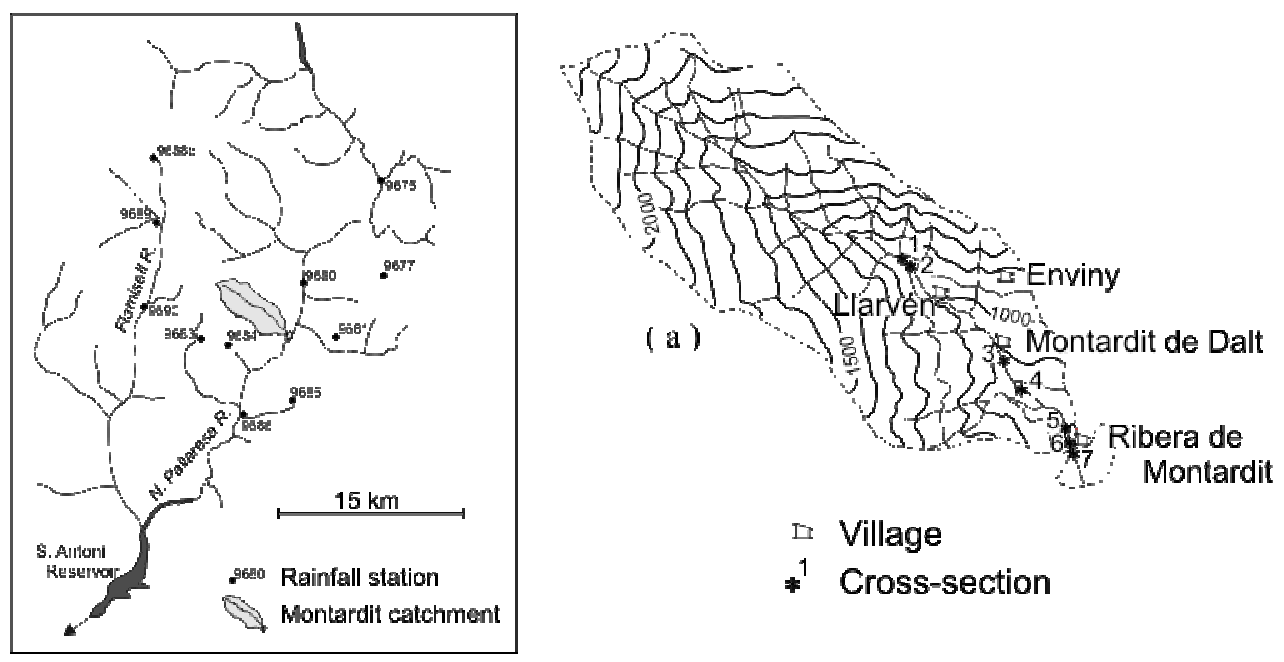

I Village

* Cross-section
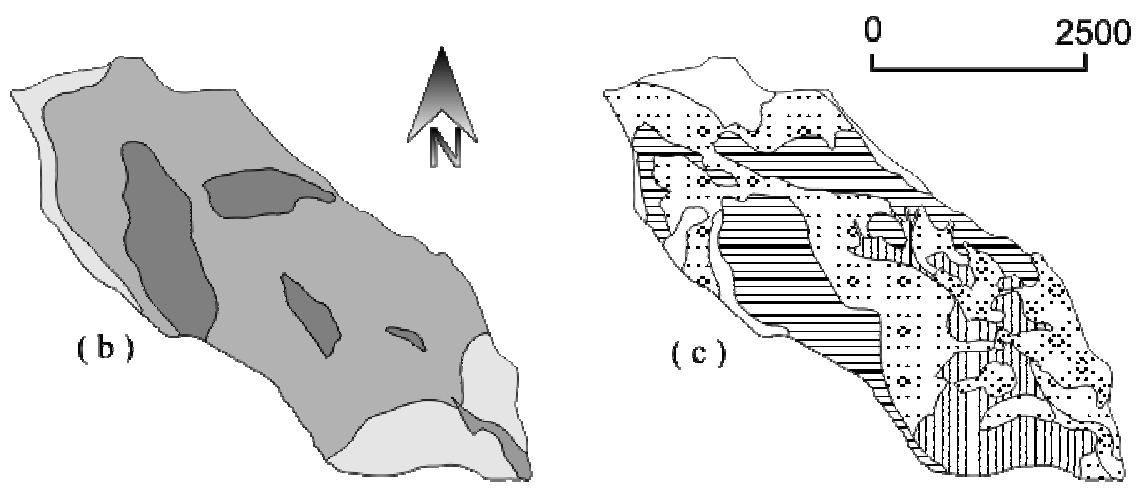

Moderate infiltration (B)

Slow infiltration (C)

Very slow infiltration (D)

$\equiv \quad$ High mountain grassland Cultivated and grassland

Woodland and brush

IIII Forest (pine and fir trees)

$\square$ Bedrock 


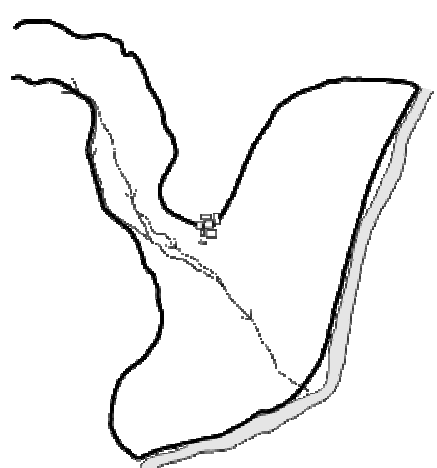

a) 1907 Flood

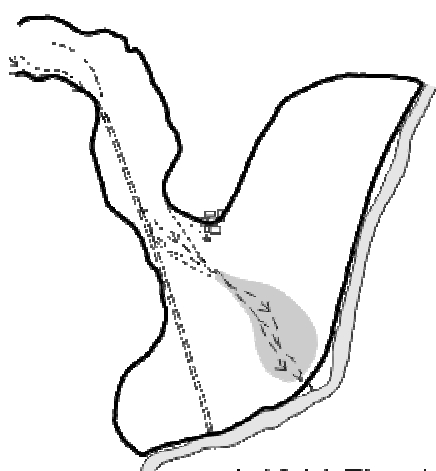

c) 1944 Flood

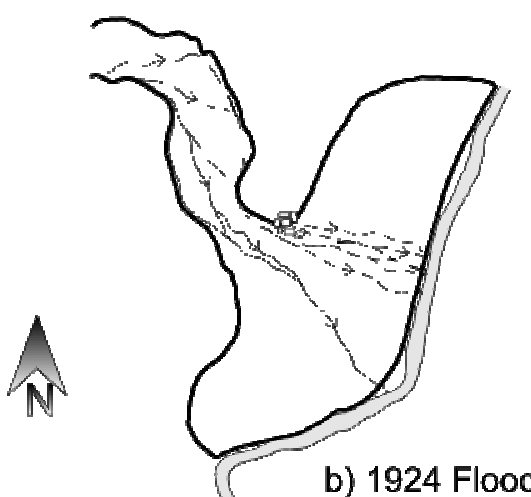

b) 1924 Flood

$$
\text { ॠ } \quad 500 \mathrm{~m}
$$

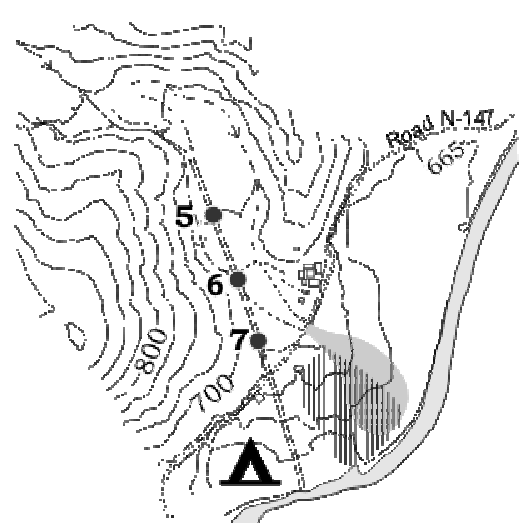

d) Present
$=:=\operatorname{Road~N}-147$

Contour line

Flood protection wall

Stream channel

Flood channel

Canal
- Delinates the alluvial fan Noguera Pallaresa River Coarse-boulder lobe

||||| Housing complex in construction

A Campsite

Village of Rivera de Montardit

5. Cross-section 


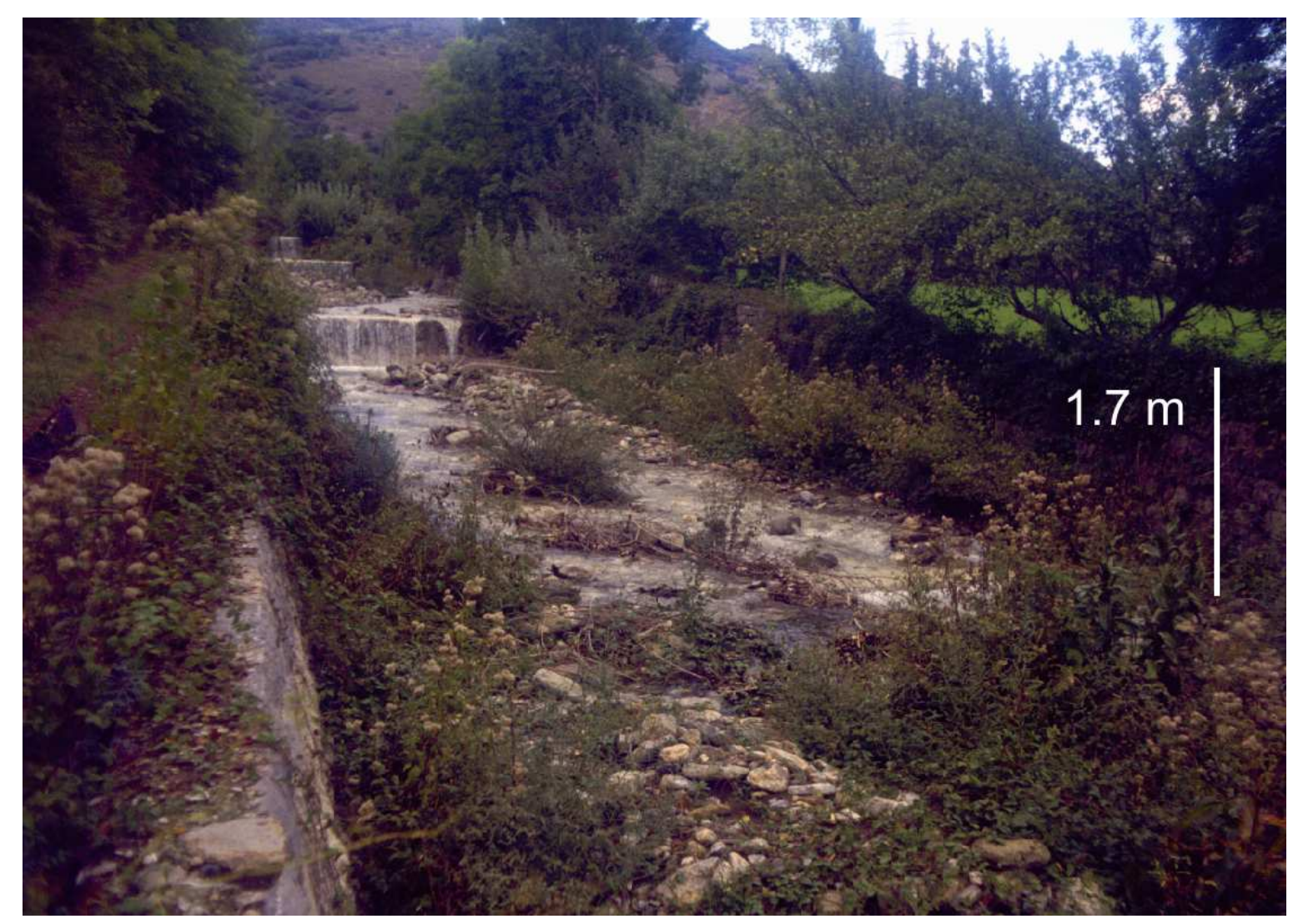



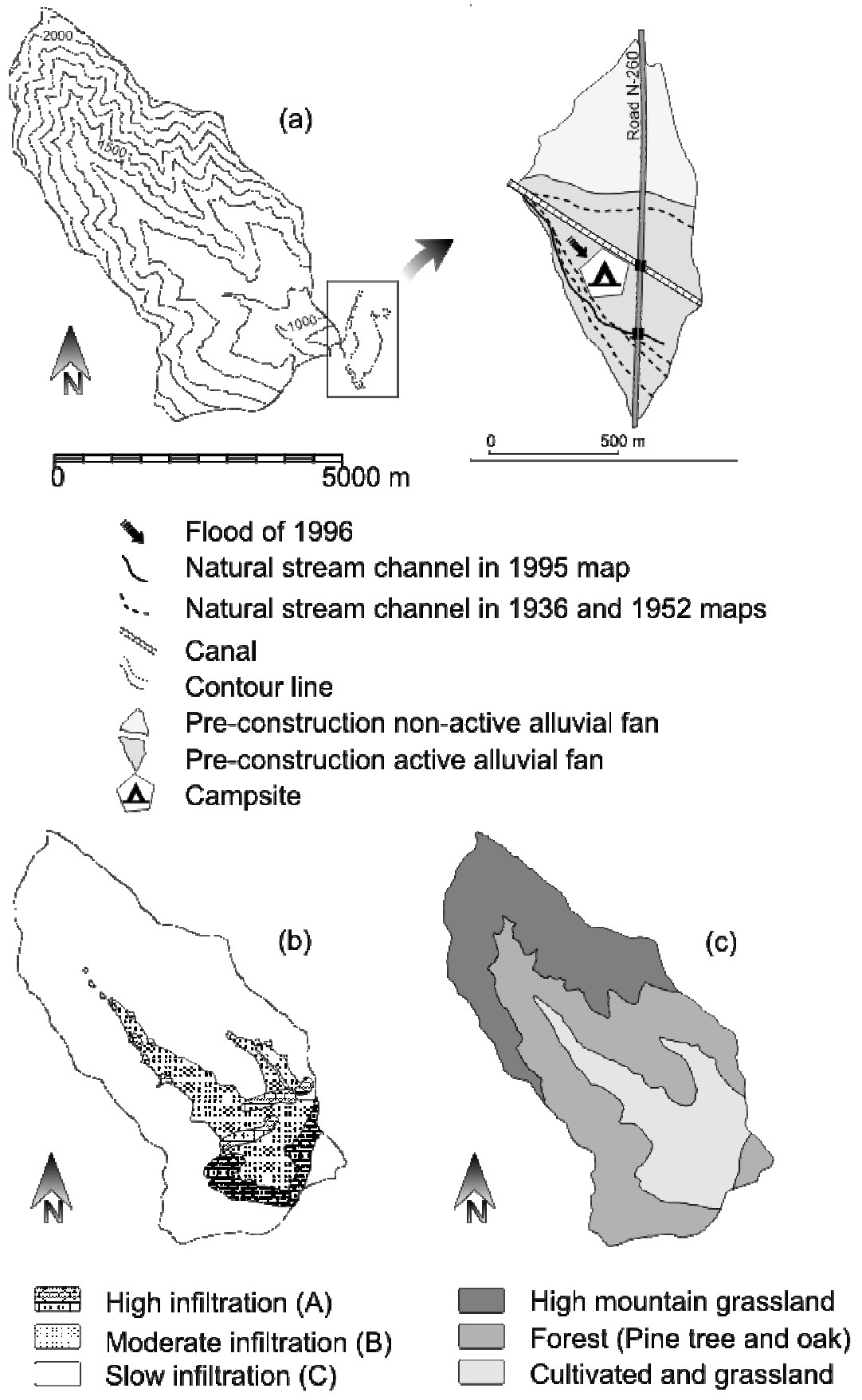